Article

\title{
Sustainable Management of Soil-Borne Bacterium Ralstonia solanacearum In Vitro and In Vivo through Fungal Metabolites of Different Trichoderma spp.
}

\author{
Yancui Guo ${ }^{1,2}$, Zhenyu Fan ${ }^{2}$, Xiong Yi $^{2}$, Yuhong Zhang ${ }^{1}$, Raja Asad Ali Khan ${ }^{3, *}$ and Zhiqiang Zhou ${ }^{1, *}$ \\ 1 Key Laboratory of Forest Plant Ecology, Ministry of Education, Northeast Forestry University, \\ Harbin 150040, China; shengmingbinfen@163.com (Y.G.); pzhangyh@126.com (Y.Z.) \\ 2 Heilongiiang Provincial Key Laboratory of Resistance Gene Engineering and Preservation of Biodiversity in \\ Cold Areas, College of Life Science, Agriculture and Forestry, Qiqihar University, Qiqihar 161006, China; \\ chahuabaoming@163.com (Z.F.); xiongyiabc@163.com (X.Y.) \\ 3 Department of Plant Pathology, The University of Agriculture, Khyber Pakhtunkhwa 25130, Pakistan \\ * Correspondence: asadraja@aup.edu.pk (R.A.A.K.); uwezhou@126.com (Z.Z.)
}

check for updates

Citation: Guo, Y.; Fan, Z.; Yi, X.; Zhang, Y.; Khan, R.A.A.; Zhou, Z. Sustainable Management of Soil-Borne Bacterium Ralstonia solanacearum In Vitro and In Vivo through Fungal Metabolites of Different Trichoderma spp.. Sustainability 2021, 13, 1491. https://doi.org/10.3390/su13031491

Academic Editor: Ugo De Corato Received: 30 December 2020

Accepted: 26 January 2021

Published: 1 February 2021

Publisher's Note: MDPI stays neutral with regard to jurisdictional claims in published maps and institutional affiliations.

Copyright: (c) 2021 by the authors. Licensee MDPI, Basel, Switzerland. This article is an open access article distributed under the terms and conditions of the Creative Commons Attribution (CC BY) license (https:// creativecommons.org/licenses/by/ $4.0 /)$.

\begin{abstract}
The efficacy of traditional control measures for the management of plant pathogens is decreasing, and the resistance of these pathogens to pesticides is increasing, which poses a serious threat to global food security. The exploration of novel and efficient management measures to combat plant disease is an urgent need at this time. In this study, fungal metabolites from three Trichoderma spp. (T. harzianum, T. virens and T. koningii) were prepared on three different growth media (STP, MOF and supermalt (SuM)). The fungal metabolites were tested in vitro and in vivo from March-April 2020 under greenhouse conditions in a pot experiment utilizing completely randomized design to test their management of the bacterial wilt disease caused by $R$. solanacearum in tomato plants. The effect of the fungal metabolites on bacterial cell morphology was also investigated through scanning electron microscopy (SEM) analysis. In vitro investigation showed that the fungal metabolites of T. harzianum obtained on the STP medium were the most effective in inhibiting in vitro bacterial growth and produced a $17.6 \mathrm{~mm}$ growth inhibition zone. SEM analysis confirms the rupture of the cell walls and cell membranes of the bacterium, along with the leakage of its cell contents. Generally, fungal metabolites obtained on an STP medium showed higher activity than those obtained on the other two media, and these metabolites were then evaluated in vivo according to three application times (0 days before transplantation (DBT), 4 DBT and 8 DBT) in a greenhouse trial to examine their ability to manage $R$. solanacearum in tomato plants. Consistent with in vitro results, the results from the greenhouse studies showed a level of higher anti-bacterial activity of T. harzianum metabolites than they did for the metabolites of other fungi, while among the three application times, the longest time (8 DBT) was more effective in controlling bacterial wilt disease in tomato plants. Metabolites of T. harzianum applied at 8 DBT caused the maximum decrease in soil bacterial population $(1.526 \log \mathrm{cfu} / \mathrm{g}$ ), resulting in the lowest level of disease severity (area under disease progressive curve (AUDPC) value: 400), and maximum plant freshness (with a resulting biomass of $36.7 \mathrm{~g}$, a root length of $18.3 \mathrm{~cm}$ and a plant height of $33.0 \mathrm{~cm}$ ). It can be concluded that T. harzianum metabolites obtained on an STP medium, when applied after 8 DBT, can suppress soil bacterial population and enhance plant growth, and thus can be used as a safe, environmentallyconscious and consumer-friendly approach to managing bacterial wilt disease in tomato plants and possibly other crops.
\end{abstract}

Keywords: biocontrol; fungus; plant disease; anti-microbial

\section{Introduction}

The tomato is the most consumed vegetable crop, and is ranked as the second most important after the potato. Because of its potential health benefits and economic importance, 
the tomato's total cultivation area and level of production is increasing globally. Approximately $182.3 \mathrm{Mt}$ of tomato fruits are produced annually on approximately 4.85 million hectares of land. China is the world's leading producer of tomatoes, accounting for $32.6 \%$ of the world's tomato production [1]. Due to having several health-promoting compounds, tomatoes can easily be incorporated into a balanced diet as sources of nutrients [2]. Tomatoes can be used as fresh fruits, as well as in many processed forms, including sauces, juices and soups [3,4]. The nutritional characteristics of tomato plants can be explained by the presence of health-promoting compounds, such as carotenoids, vitamins and phenolic compounds $[2,4-6]$. Tomatoes also have a range of other nutritionally important metabolites, including ascorbic acid, sucrose, hexoses, malate and citrate [4].

Tomato production faces several challenges globally. Several factors (such as management strategies, diseases, cultivar selection, pests, etc.) can affect tomato yield and production, the most important of which are diseases [7,8]. Among the effects caused by diseases, the bacterial wilt caused by Ralstonia solanacearum is one of the most serious symptoms afflicting the tomato plant, causing huge losses in yield worldwide in warm temperature, sub-tropical and tropical regions [9-12]. In China, bacterial wilt disease commonly occurs in the eastern and southern regions rather than in the western and northern regions. The 30 provinces listed in the study of Jiang, G. et al. have reported high incidences of bacterial wilt [13]. Depending on the soil temperature and crop season, the disease incidence in tomato fields ranges between $10 \%$ and $95 \%$ [14-16].

$R$. solanacearum is a Gram-negative soil-borne plant pathogenic bacteria that causes huge losses to agriculture worldwide [17]. The bacterium has a wide host range, infecting more than 200 plant species. Infection starts via the penetration of root tissues, then aggressive colonization occurs on the root system of the infected plant and leads to a systemic spread of the pathogen, producing shoot symptoms $[18,19]$. $R$. solanacearum can live in soil for a long time in several environments $[20,21]$. The bacterium's soil-borne nature, survivability in different environments, genetic diversity and wide host range make it difficult to manage. However, an integrated disease management approach combining host plant resistance with cultural and biological control measures appears to be effective. Although attempts have been made to manage $R$. solanacearum with different level of success, there is still a great opportunity to solve this problem by finding a stable solution.

A potential solution for the management of plant pathogens (which is also environmentallyconscious and consumer-friendly) is the utilization of bioactive metabolites/compounds obtained from microorganisms [22]. Among microorganisms, fungi are special in their production of a variety of anti-microbial metabolites. Several fungus genera are well known for their capacity to produce organic acids, antibiotics, enzymes, vitamins and polysaccharides [23]. Among fungi, the genus Trichoderma contains fungal species that are well-studied biocontrol agents today $[24,25]$. Bioactive metabolites secreted by Trichoderma spp. can be useful to several industries, as well as to the agricultural and medical fields. These Trichoderma metabolites, including terpenes, pyrones, gliotoxin, gliovirin, peptaibols and polyketides, exhibit anti-microbial activities against several plant pathogenic bacteria, yeasts and fungi [26-28]. The metabolite production ability of the fungus is generally species/isolate dependent. A given Trichoderma species can secrete various metabolic compounds and, in a similar manner, a given compound can be secreted by different Trichoderma species [29]. Moreover, different isolates of the same species can produce different compounds [30]. Recently, soil applications of Trichoderma spp. in the form of fungal suspension were evaluated for their ability to manage $R$. solanacearum in potato crops [31,32]. However, the efficacy of Trichoderma metabolites in the management of the bacterial wilt of tomato plants has not been reported yet. In this study, the metabolites were prepared from three Trichoderma spp. on three different growth media and evaluated in vitro for their anti-bacterial potential against $R$. solanacearum. Those metabolites that showed higher activity were further evaluated in vivo to test their management of the bacterial wilt disease caused by $R$. solanacearum in tomato plants at three different application times in a greenhouse trial. Scanning electron microscopy (SEM) analysis was also conducted to observe the morphological destruction 
of the bacterial cell at a cellular level, and soil bacterial population was investigated under the influence of fungal metabolites.

\section{Materials and Methods}

\subsection{Fungal and Bacterial Cultures}

The pre-identified preserved fungal cultures of T. harzianum (T180), T. virens (T136) and T. koningii (T176) and a bacterial culture of $R$. solanacearum (RS13) were procured from College of Life Science, Agriculture and Forestry, Qiqihar University in 2020. The fresh culture of bacteria was obtained from a lysogeny broth (LB) medium incubated at $28{ }^{\circ} \mathrm{C}$ for $24-48 \mathrm{~h}$, while fresh fungal cultures were obtained from a potato dextrose agar (PDA) medium incubated at $28{ }^{\circ} \mathrm{C}$ for 7-10 days [33].

\subsection{Fungal Metabolites Preparations}

Three fungal species were grown on three liquid media to produce anti-bacterial metabolites. The detailed recipe of the media is given in Table S1. From the freshly prepared fungal culture, five plugs were added to a $100 \mathrm{~mL}$ fungal seed medium (with a composition of $10 \mathrm{~g}$ of yeast extract, $4 \mathrm{~g}$ of agar, $40 \mathrm{~g}$ of maltose and $10 \mathrm{~g} / \mathrm{L}$ of bactoneopeptone) in one $500 \mathrm{~mL}$ flask and kept on shaking incubation for 4 days at $25^{\circ} \mathrm{C}$ [33]. Then, $5 \mathrm{~mL}$ of the obtained culture broth was used to inoculate each of the flasks containing $100 \mathrm{~mL}$ of the three liquid media used in this study and incubated at $25{ }^{\circ} \mathrm{C}$ for 2 weeks. After 2 weeks, the fungal metabolites were extracted using the extraction solvent ethyl acetate [33]. After drying the extraction solvent, the fungal metabolites were collected, preserved at $4{ }^{\circ} \mathrm{C}$ and used for their anti-bacterial potential against $R$. solanacearum.

\subsection{In Vitro Test}

The anti-bacterial efficacy of the fungal metabolites was checked using the agar well diffusion method [34]. The fungal metabolites were dissolved in methanol to a concentration of $150 \mathrm{mg} \mathrm{mL}^{-1}$. In a petri plate, the LB medium, with $0.5 \mathrm{~mL}$ of bacterial suspension $\left(10^{8} \mathrm{cfu}\right)$, was poured and allowed to cool to solidification. A total of five wells of uniform size were made in the solidified LB medium. Three wells were filled with $10 \mu \mathrm{L}$ of the fungal metabolites obtained from the three growth media, one well was filled with a positive control (streptomycin (an antibiotic)) and one well was filled with a negative control (methanol). The plates were incubated at $28{ }^{\circ} \mathrm{C}$ for $24 \mathrm{~h}$, and anti-bacterial activity was evaluated by measuring the inhibition zone. The test was repeated once, with five replicates in each test, and the results were presented as mean values.

\subsection{Morphological Observation of the Bacterial Cells}

The morphological destruction of the bacterial cells was evaluated using scanning electron microscopy (SEM). The bacterial samples were prepared by cutting small pieces of agar (with a thickness of $5 \mathrm{~mm}$ ) from both the untreated control and from the inhibition zone of the best treatment and fixed in $2.5 \%(v / v)$ glutaraldehyde for one hour. After being washed with the phosphate buffer, the agar pieces were fixed in $1 \%(w / v)$ osmium tetroxide. The samples were then washed in a phosphate buffer and dehydrated in 30\%,50\%,70\%, $90 \%$, and 95\% ethanol series, for 15 minutes each. After this, the samples were subjected to $100 \%$ ethanol and $\mathrm{CO}_{2}$. The fully dried samples were coated with gold sputtering and used for SEM analysis [35].

\subsection{In Vivo Test}

The fungal metabolites obtained on the STP medium (showing maximum in vitro anti-bacterial activity) were tested in vivo for their ability to manage $R$. solanacearum in tomato plants under greenhouse conditions. In brief, plastic pots with a diameter of $20 \mathrm{~cm}$ were filled with $1 \mathrm{~kg}$ of sterilized soil per pot. Thirty-five $\mathrm{mL}$ of a bacterial suspension $\left(10^{8} \mathrm{cfu} \mathrm{mL} \mathrm{m}^{-1}\right)$ was poured in the center of each pot. For each of the three Trichoderma species tested, $15 \mathrm{~mL}$ of the fungal metabolites $(9 \% \mathrm{w} / \mathrm{v})$ obtained after a fungus cultivation on the 
STP medium were applied to the soil at three positions in the center of each pot 3 days after bacterial inoculation of the soil. One healthy tomato seedling of uniform size ( 25 days old) was transplanted into each pot. The fungal metabolites were applied separately at three different application times (i.e., 0, 4 and 8 days before transplantation (DBT)). The irrigation and fertilizer requirements were fulfilled according to the horticultural recommendations for tomato plants [36]. The experiment was repeated once, with five replications of the experiment conducted without any modification.

\subsection{Data Parameters}

The experiment was terminated after the 60th day since the transplantation was completed and the data on different plant growth parameters (i.e., fresh biomass, root length, plant height, bacterial population in soil and disease severity) were recorded.

\subsection{Bacterial Population in Soil}

To measure the number of bacteria in soil, four samples of soil cores were collected randomly from a 10-12 cm depth in each pot, and a composite sample was made by mixing the four samples together [37]. Three sub-samples were made from the composite samples and diluted serially up to $10^{-7}$. The $100 \mu \mathrm{L}$ suspension from each sub-sample was poured on a petri plate containing $25 \mathrm{~mL}$ of the selective media tetrazolium chloride nutrient agar TZCNA [38]. The bacterial colonies with an off-white color and red center were counted and soil bacterial population was presented in terms of $\mathrm{cfu}^{-1}$ of soil.

\subsection{Area under Disease Progressive Curve (AUDPC)}

The disease severity of the bacterial wilt affecting the tomato plants was recorded using a specified scale and converted to \% disease severity [39]. The disease severity was measured 5 times every 12 days and converted to an AUDPC value using the AUDPC formula [40].

\subsection{Statistical Analysis}

Results were presented as mean values \pm standard deviation. Analysis was done using ANOVA with IBMSPSS Statistix 20 software. Factorial arrangements were applied to both in vitro and in vivo data. Least significant difference (LSD) test was conducted to indicate significant differences among the treatments [41].

\section{Results}

\subsection{In Vitro Test}

Fungal metabolites of the three Trichoderma spp. (T. harzianum, T. virens and T. koningii) obtained on three different growth media (STP, MOF and supermalt (SuM)) were tested for in vitro anti-bacterial activity against $R$. solanacearum. Significant differences in antibacterial activity were observed among the treatments (Figures 1 and 2). Among different fungal species, the fungal extracts of T. harzianum showed the highest anti-bacterial activity, and across different media, the fungal metabolites obtained on the STP media showed the highest anti-bacterial activity. The fungal metabolites obtained on the MOF and SuM media exhibited similar anti-bacterial activity from all three fungal species. After that of the positive control (streptomycin), the maximum growth inhibition zone was produced by the fungal metabolites of T. harzianum obtained on the STP media, followed by the T. virens fungal extracts obtained on the STP media. Growth inhibition zones of $17.6 \mathrm{~mm}, 13.1 \mathrm{~mm}$ and $12.6 \mathrm{~mm}$ were produced by T. harzianum metabolites obtained on the STP, MOF and SuM media, respectively. The inhibition zones for T. virens metabolites obtained on the STP, MOF and SuM media were recorded as $13.2 \mathrm{~mm}, 9.6 \mathrm{~mm}$ and $8.1 \mathrm{~mm}$, respectively, while T. koningii metabolites obtained on STP, MOF and SuM media produced $10.3 \mathrm{~mm}, 7.4 \mathrm{~mm}$ and $7.2 \mathrm{~mm}$ growth inhibition zones, respectively. The negative control methanol did not show any activity and produced no inhibition zone. 


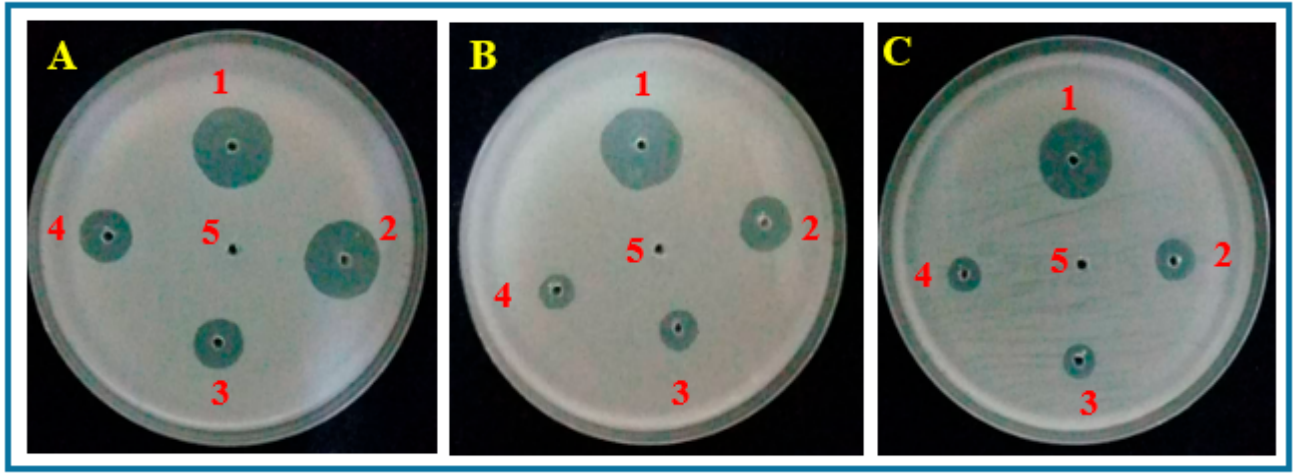

Figure 1. Zones of inhibition produced by fungal metabolites of Trichoderma spp. obtained on different growth media. A: T. harzianum, B: T. virens and C: T. koningii. 1: Streptomycin (positive control), 2: STP media, 3: MOF media, 4: Supermalt (SuM) media and 5: Methanol (negative control).

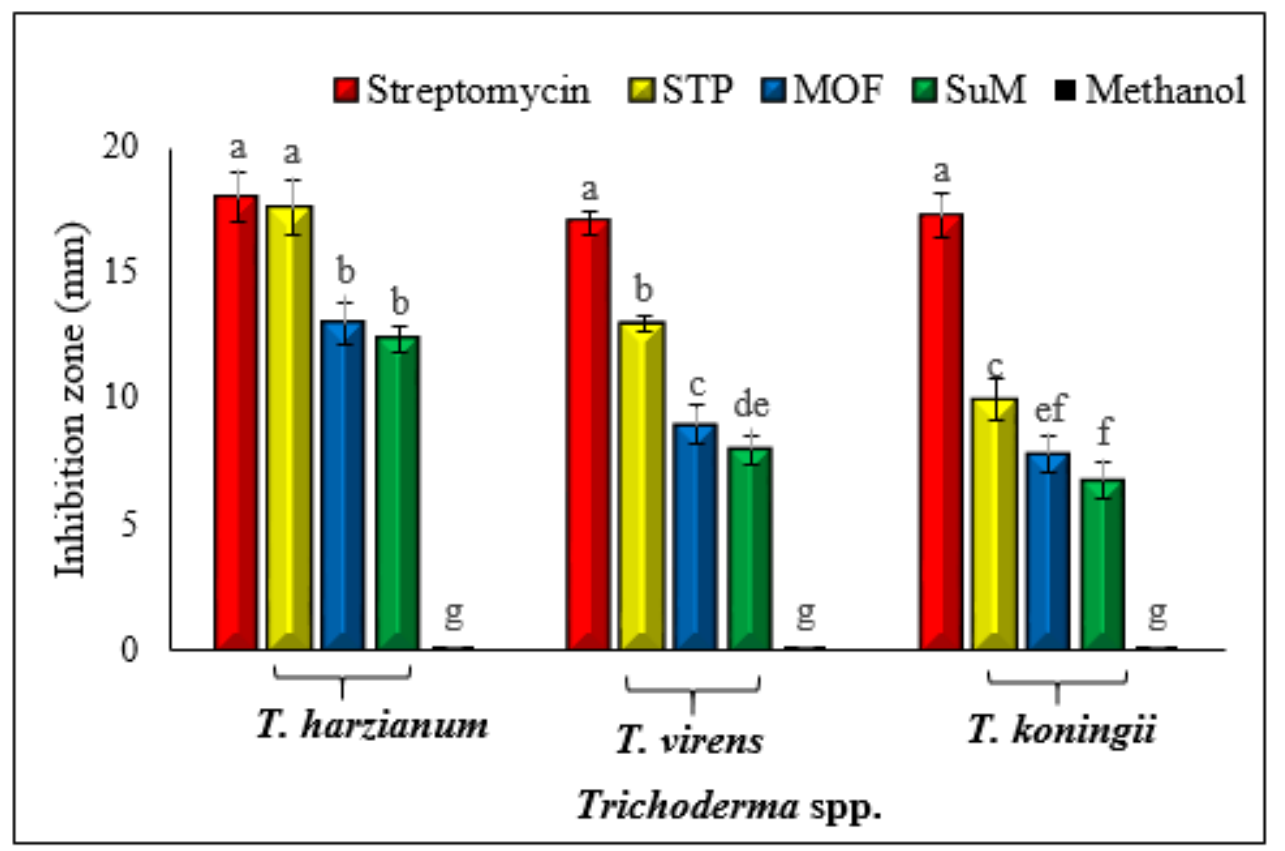

Figure 2. Anti-bacterial activity of fungal metabolites of Trichoderma spp. obtained on different growth media. Each value is a mean of five replicates \pm standard deviation. Means with similar lettering shows no significant difference among the treatments $(p \leq 0.05)$, as per Fisher's protected least significant difference (LSD) test.

\subsection{Bacterial Cell Morphology}

The morphological alterations in bacterial cells were observed through SEM analysis. The treated and untreated bacterial cells exhibited a clear difference in their morphology (Figure 3). The morphology of bacterial cells treated with fungal metabolites (the most effective treatment of which was T. harzianum metabolites obtained on STP media) underwent tremendous destruction. The cell content leakage, cell wall degradation and membrane breakdown can be easily observed. The bacterial cells belonging to control group (without any treatment) showed normal rod-shaped uniform bacterial morphology without any interference. 


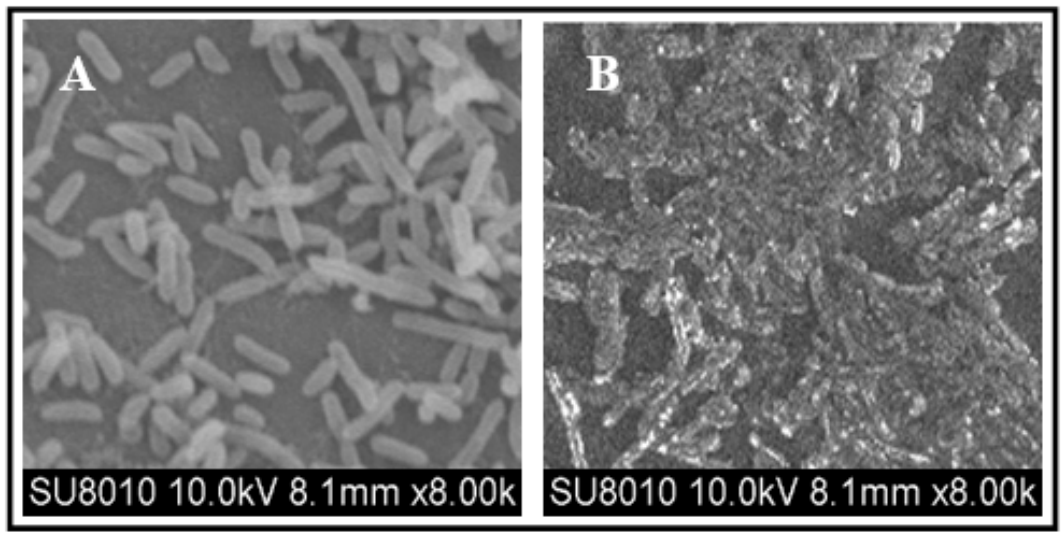

Figure 3. Scanning electron microscopy (SEM) micrograph of Ralstonia solanacearum cells (A) in the control without treatment and (B) under the influence of T. harzianum metabolites obtained on STP.

\subsection{Plant Growth}

In a green house experiment, the fungal metabolites of three Trichoderma spp. (T. harzianum, T. virens and T. koningii) obtained on an STP medium and applied at three different times $(0,4$ and 8 DBT) were evaluated for their ability to manage bacterial wilt disease in tomato plants. The results showed significant differences both for Trichoderma spp. and application times in terms of affecting plant growth parameters such as fresh biomass, root length and plant height (Figure 4). Among the three application times, 8 DBT gave the best results, and among the three fungal metabolites, the T. harzianum metabolites gave the best results. The maximum fresh biomass $(51.3 \pm 3.6 \mathrm{~g})$, root length $(27.4 \pm 2.4 \mathrm{~mm})$ and plant height $(46.3 \pm 3.1)$ were achieved when $T$. harzianum metabolites were applied at 8 DBT. The minimum effect on plant growth was noticed for the treatment combination of $T$. koningii and 0 DBT that gave $25.2 \pm 1.7 \mathrm{~g}, 10.5 \pm 0.9 \mathrm{~cm}$ and $16.5 \pm 2.1 \mathrm{~cm}$ in fresh biomass, root length and plant height, respectively. A similar trend in the results was noticed in the repeated experiment, where the application time $8 \mathrm{DBT}$ and the fungal metabolites of T. harzianum gave the best plant growth as compared to other application times and fungal metabolites (Tables 1-3, Experiment II).



Figure 4. Tomato plants grown in soil inoculated with $R$. solanacearum and treated with fungal metabolites applied at 8 days before transplantation (DBT). 1: Control (inoculated and untreated), 2: T. konigii metabolites, 3: T. virens metabolites and 4. T. harzianum metabolites. 
Table 1. Effect of fungal metabolites applied at different application times on fresh biomass (g) of tomato plants grown in soil inoculated with $R$. solanacearum.

\begin{tabular}{ccccc}
\hline \multirow{2}{*}{$\begin{array}{c}\text { Application } \\
\text { Time (DBT) }\end{array}$} & \multicolumn{4}{c}{ Trichoderma spp. } \\
\cline { 2 - 5 } & T. harzianum & T. virens & T. koningii & Control \\
\hline \multicolumn{5}{c}{ Experiment I } \\
\hline 4 & $32.1 \pm 3.1 \mathrm{c}$ & $27.3 \pm 2.5 \mathrm{de}$ & $25.2 \pm 1.7 \mathrm{e}$ & $24.4 \pm 1.8 \mathrm{e}$ \\
8 & $40.3 \pm 3.1 \mathrm{~b}$ & $33.4 \pm 3.2 \mathrm{c}$ & $27.7 \pm 2.7 \mathrm{de}$ & $24.2 \pm 1.9 \mathrm{e}$ \\
& $51.3 \pm 3.6 \mathrm{a}$ & $39.7 \pm 2.9 \mathrm{~b}$ & $30.4 \pm 2.8 \mathrm{~cd}$ & $25.6 \pm 2.5 \mathrm{e}$ \\
\hline 0 & & Experiment II & \\
\hline & $35.5 \pm 2.8 \mathrm{ef}$ & $33.2 \pm 3.1 \mathrm{ef}$ & $30.3 \pm 2.8 \mathrm{f}$ & $28.5 \pm 2.3 \mathrm{f}$ \\
\hline & $46.1 \pm 2.9 \mathrm{~b}$ & $41.6 \pm 3.2 \mathrm{c}$ & $35.4 \pm 3.4 \mathrm{ef}$ & $29.3 \pm 2.2 \mathrm{f}$ \\
\hline
\end{tabular}

Each value is a mean of five replicates \pm standard deviation. Similar lettering shows no significant difference among the treatments $(p \leq 0.05)$ as per Fisher's protected LSD test.

Table 2. Effect of fungal metabolites applied at different application times on root length (cm) of tomato plants grown in soil inoculated with $R$. solanacearum.

\begin{tabular}{ccccc}
\hline \multirow{2}{*}{$\begin{array}{c}\text { Application } \\
\text { Time (DBT) }\end{array}$} & \multicolumn{4}{c}{ Trichoderma spp. } \\
\cline { 2 - 5 } & T. harzianum & T. virens & T. koningii & Control \\
\hline \multicolumn{5}{c}{ Experiment I } \\
\hline 0 & $17.4 \pm 2.1 \mathrm{c}$ & $14.3 \pm 1.4 \mathrm{ef}$ & $10.5 \pm 0.9 \mathrm{gh}$ & $9.2 \pm 1.1 \mathrm{hi}$ \\
8 & $20.6 \pm 1.6 \mathrm{~b}$ & $16.4 \pm 1.3 \mathrm{~cd}$ & $12.2 \pm 1.0 \mathrm{fg}$ & $9.1 \pm 0.8 \mathrm{hi}$ \\
\hline & $27.4 \pm 2.4 \mathrm{a}$ & $22.3 \pm 2.1 \mathrm{~b}$ & $15.6 \pm 1.6 \mathrm{de}$ & $8.1 \pm 0.9 \mathrm{i}$ \\
\hline & & Experiment II & \\
\hline & $19.2 \pm 2.3 \mathrm{c}$ & $16.6 \pm 2.1 \mathrm{~d}$ & $14.3 \pm 1.7 \mathrm{de}$ & $12.4 \pm 1.4 \mathrm{e}$ \\
\hline & $23.4 \pm 2.1 \mathrm{~b}$ & $19.7 \pm 1.8 \mathrm{c}$ & $16.2 \pm 1.4 \mathrm{~d}$ & $13.5 \pm 1.2 \mathrm{e}$ \\
\hline
\end{tabular}

Each value is a mean of five replicates \pm standard deviation. Similar lettering shows no significant difference among the treatments $(p \leq 0.05)$ as per Fisher's protected LSD test.

Table 3. Effect of fungal metabolites applied at different application times on plant height (cm) of tomato plants grown in soil inoculated with $R$. solanacearum.

\begin{tabular}{ccccc}
\hline \multirow{2}{*}{$\begin{array}{c}\text { Application } \\
\text { Time (DBT) }\end{array}$} & \multicolumn{4}{c}{ Trichoderma spp. } \\
\cline { 2 - 5 } & T. harzianum & T. virens & T. koningii & Control \\
\hline \multicolumn{5}{c}{ Experiment I } \\
\hline 4 & $23.9 \pm 2.6 \mathrm{~d}$ & $18.3 \pm 2.4 \mathrm{e}$ & $16.5 \pm 2.1 \mathrm{e}$ & $15.8 \pm 1.8 \mathrm{e}$ \\
8 & $40.6 \pm 3.3 \mathrm{~b}$ & $33.3 \pm 2.4 \mathrm{c}$ & $26.3 \pm 1.9 \mathrm{~d}$ & $17.2 \pm 1.2 \mathrm{e}$ \\
& $46.3 \pm 3.3 \mathrm{a}$ & $38.5 \pm 3.1 \mathrm{~b}$ & $32.3 \pm 2.6 \mathrm{c}$ & $15.0 \pm 1.5 \mathrm{e}$ \\
\hline 0 & $25.6 \pm 2.6 \mathrm{~d}$ & $23.2 \pm 2.5 \mathrm{de}$ & $19.6 \pm 3.2 \mathrm{e}$ & $20.3 \pm 2.1 \mathrm{e}$ \\
4 & $39.2 \pm 2.8 \mathrm{~b}$ & $31.3 \pm 2.7 \mathrm{c}$ & $25.5 \pm 2.2 \mathrm{~d}$ & $19.2 \pm 1.3 \mathrm{e}$ \\
8 & $47.3 \pm 3.1 \mathrm{a}$ & $40.6 \pm 2.2 \mathrm{~b}$ & $32.2 \pm 2.5 \mathrm{c}$ & $18.1 \pm 2.1 \mathrm{e}$
\end{tabular}

Each value is a mean of five replicates \pm standard deviation. Similar lettering shows no significant difference among the treatments $(p \leq 0.05)$ as per Fisher's protected LSD test.

\subsection{Soil Bacterial Population}

At the beginning and the end of the experiment, the soil bacterial population was counted. The difference in the number of bacteria from the beginning to the end is classified by the decrease in bacterial population. The results showed that soil treatment with fungal extracts significantly affected the soil bacterial population. The three application times of 
the fungal extract also showed significant differences regarding the decrease in soil bacterial population. Among application times, the 8 DBT was the most effective at suppressing soil bacterial population, especially when combined with $T$. harzianum metabolites, which were the most highly active of the fungal metabolites in suppressing soil bacterial population. T. harzianum metabolites applied at 8 DBT showed a maximum decrease of $1.526 \mathrm{log} \mathrm{cfu} / \mathrm{g}$ in soil bacterial population, followed by the decrease exhibited by T. virens. Meanwhile, among all the treatments, T. konigii metabolites applied at 0 DBT exhibited the lowest decrease $(0.686 \log \mathrm{cfu} / \mathrm{g})$ in soil bacterial population (Figure $5 \mathrm{~A})$. Similar results were shown by the treatments when the experiment was repeated (Figure 5B).

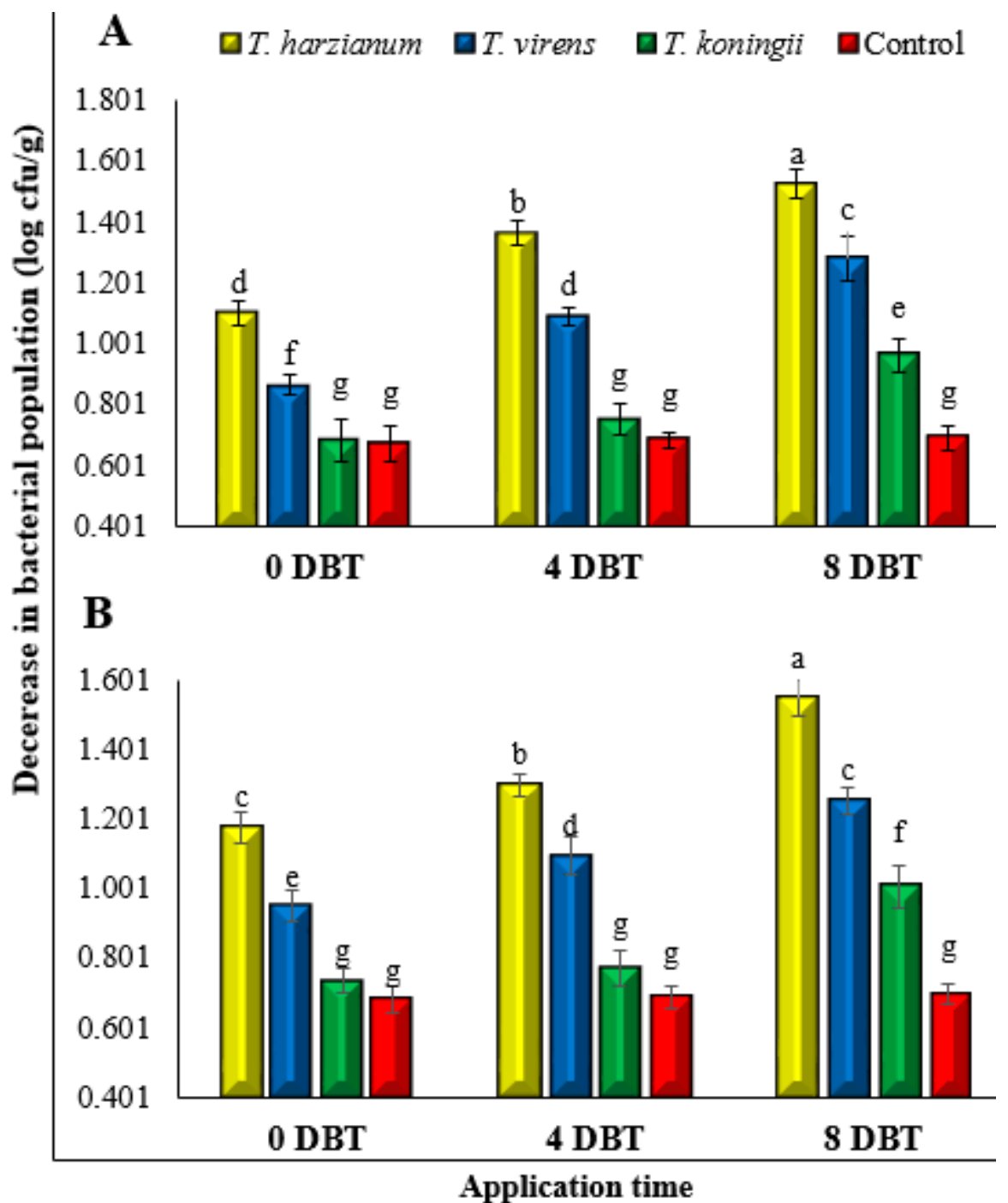

Figure 5. Decrease in soil bacterial population (in log cfu/g) affected by fungal metabolites of T. harzianum, T. virens and T. koningi obtained on the STP medium applied at different application times (0 DBT, 4 DBT and 8 DBT). Each value is a mean of five replicates \pm standard deviation. Means having similar lettering shows no significant difference among the main effect $(p \leq 0.05)$ as per Fisher's protected LSD test. A: Experiment I. B: Experiment II.

\subsection{AUDPC}

The data recorded on disease severity of the tomato plants grown in soil treated with fungal extracts at different application times were changed to AUDPC. Results showed significant differences among the treatments. The plants grown in untreated control soil showed the maximum AUDPC value and died completely. Compared to the control, the 
plants grown in treated soil exhibited lower AUDPC values. Among fungal spp., the metabolites of T. harzianum were the most effective in lowering the AUDPC value, and among application times, 8 DBT was the most effective in lowering the AUDPC value. The fungal metabolites of T. harzianum applied at 8 DBT had the lowest AUDPC value (400). The maximum AUDPC value (1750) was shown by plants grown in soil treated with T. koningi applied at 0 DBT (Figure 6A). The experiment was repeated without any modification and similar results were obtained (Figure 6B).

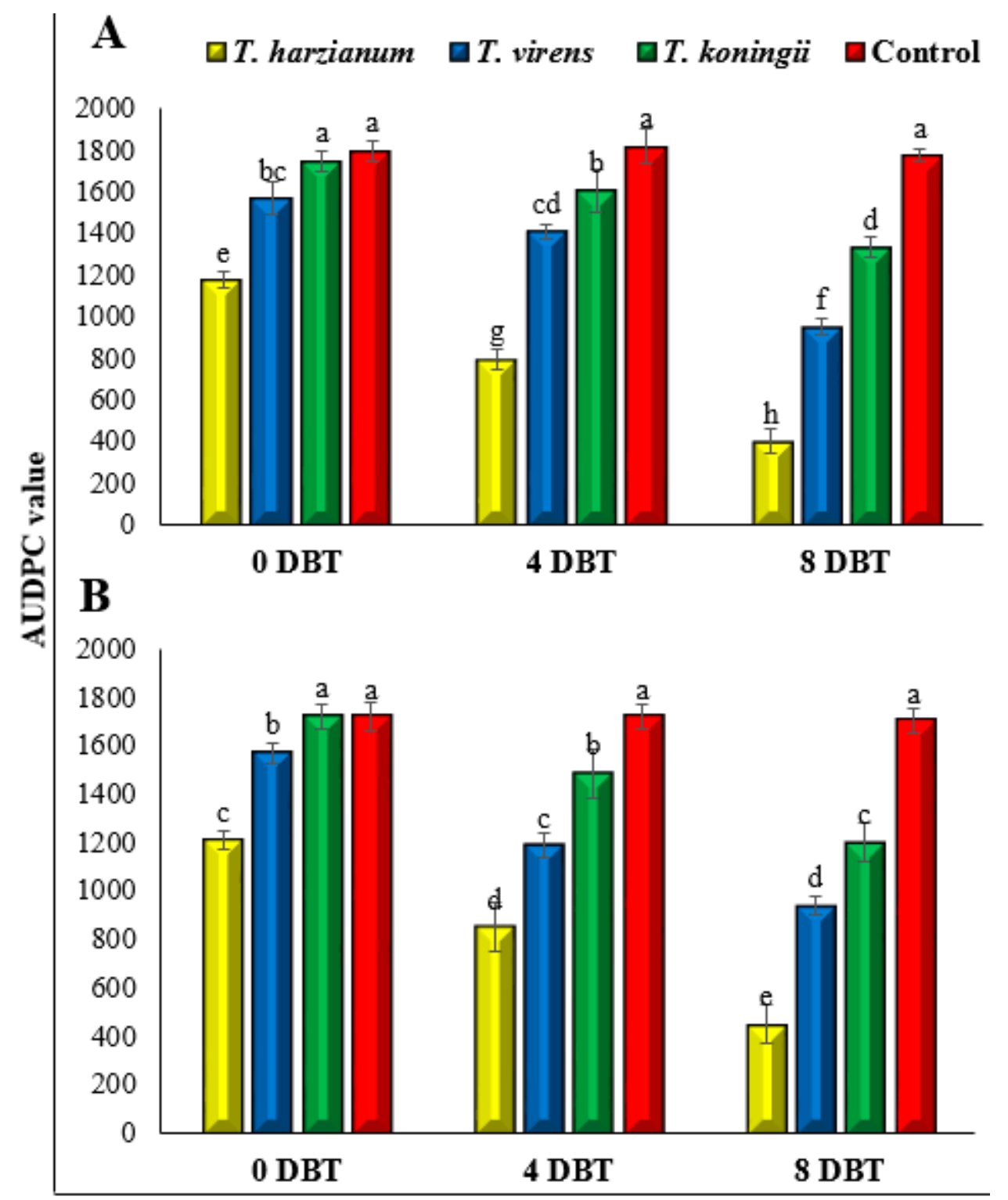

Application time

Figure 6. The area under disease progressive curve (AUDPC) affected by the fungal metabolites of T. harzianum, T. virens and T. koningi obtained on an STP medium applied at different application times (0 DBT, 4 DBT and 8 DBT). Each value is a mean of five replicates \pm standard deviation. Means having similar lettering shows no significant difference among the main effect $(p \leq 0.05)$ as per Fisher's protected LSD test. A: Experiment I and B: Experiment II. 


\section{Discussion}

Managing phytopathogens through the metabolites of biocontrol agents that are biologically active is a potentially environmentally-conscious and consumer friendly approach [22]. In this study, the metabolites of three Trichoderma spp. obtained on three different growth media, were tested for their anti-bacterial potential in managing $R$. solanacearum both in vitro and in vivo in tomato plants.

The results from in vitro evaluation showed the strong bioactivity of the fungal extracts. All of the fungal metabolites were not equally active against $R$. solanacearum. Generally, the fungal metabolites of T. harzianum exhibited higher anti-bacterial activity, followed by the fungal metabolites of $T$. virens and $T$. koningi. This is due to the fact that different species (as well as different strains) of the fungus produce different secondary metabolites (SMs). It is reported that different Trichoderma isolates exhibited different extents of anti-microbial activity against pathogens [32]. The results obtained in this study are in line with previously reported results, in which metabolites of different Trichoderma spp. were evaluated in vitro against different plant pathogens, and it was found that $T$. harzianum metabolites were more active than other species [33]. The anti-bacterial activity of the fungal metabolites could be attributed to the several anti-bacterial compounds present in the metabolites. Different bioactive compounds have previously been reported from Trichoderma spp. and used against plant pathogenic bacteria [42-45]. Several studies have also reported the ability of SMs to inhibit nucleic acid and cell wall synthesis and destroy membranes [46-48]. The lysosime was reported to cause membrane breakdown and cell content leakage, which lead to cell death [49]. The analysis of bacterial cell morphology in this study also confirms that these mechanisms (such as the disintegration of bacterial cell wall and membranes) can be easily seen in SEM micrographs.

The results from the in vivo tests indicated that fungal metabolites, when applied to soil infested with $R$. solanacearum, can suppress the bacterial population in soil, reducing the disease severity and improving plant growth. Consistent with the results of the in vitro tests, the fungal metabolites of T. harzianum were more active than the metabolites of other fungus. This is because the fungal metabolites of $T$. harzianum may have stronger anti-microbial metabolites against $R$. solanacearum. The ability of the anti-biotic production is usually isolate or species dependent. A specific anti-biotic can be produced by different fungal species, and, in a similar way, a specific fungal species can produce several bioactive compounds [29]. The secretion of anti-microbial compounds is one of the major anti-microbial mechanisms of a biocontrol agent. It is reported that the use of fungal metabolites against the pathogens exhibited similar results that the same processes achieved through corresponding micro-organisms [28]. The improved plant growth resulting from the application of fungal metabolites can also be explained on the basis of the plant growth promoting properties of Trichoderma metabolites. Along with direct antagonistic or parasitic activity against pathogenic microbes, Trichoderma spp. also secrete various compounds that alter the host metabolism positively and affect its development and growth. It was reported that plant seeds exhibited increased productivity when exposed to conidia of Trichoderma spp., which suggests that metabolites from Trichoderma spp. can act as signaling compounds in addition to promoting plant growth effects [50]. Several Trichoderma strains are capable of producing secondary metabolites involved in auxin-dependent mechanisms to enhance root growth and increase plant biomass [51,52]. The role of fungal metabolites (i.e., koninginins A, B, C, E and G isolated from T. koningii and 6-pentyl-alpha-pyrone isolated from $T$. harzianum) as growth regulators in wheat plants was reported by several studies [53-56]. Trichocaranes A, B, C and D produced by T. virens significantly affected the growth of etiolated wheat coleoptiles [57]. A sesquiterpene metabolite cyclonerodiol obtained from culture filtrate of T. harzianum and T. koningii demonstrated a regulatory effect on plant growth $[58,59]$. The direct toxic effect to the $R$. solanacearum, as well as the plant growth promoting effect of compounds present in the fungal metabolites, collectively contributed to enhanced plant growth. As discussed above, the anti-bacterial compounds affect the bacterial population in a variety of ways, including targeting membranes and 
DNA and causing protein destructions $[45,47,48]$. This direct toxic effect of fungal metabolites contributes largely to a higher decrease in the soil bacterial population, resulting in a lower disease severity (or AUDPC) and the resulting enhanced plant growth.

It was noted that a longer application time (8 DBT) was superior to shorter application times (4 DBT and $0 \mathrm{DBT}$ ). This is because the longer application time helps in thorough mixing, as well as increasing the stability and compatibility of fungal metabolites in the soil, resulting in increased activity of the extract. Our results are in line with the findings of Khan et al. [60], where an organic soil amendment with different application times was used to test its management of $R$. solanacearum in tomato plants. The results suggested that a longer application time exhibited the best results because of the increased stability and compatibility of the treatments, which, in turn, release more anti-microbial compounds in the soil. The fungal extract was prepared on low cost media without the use of heavy mechanical or chemical involvement. The extract was active at a low concentration and effectively reduced soil bacterial population and improved plant growth. The fungi belonging to the Trichoderma genus are well known and widely used as biocontrol agents. Recently, the management of bacterial wilt disease was enacted through direct application of the Trichoderma spp. to the soil [31,32]. However, the metabolites were not evaluated beforehand for their ability to manage bacterial wilt disease in tomato plants and other crops. The results of this study indicated the potential of Trichoderma metabolites to manage $R$. solanacearum on tomato plants. However, such potential can be evaluated only in comparison with other protection techniques applied currently on tomato plants against this pathogen. This study will also provide a basis for the commercial preparation of Trichoderma metabolites in the market for the purpose of managing $R$. solanacearum in tomato plants and possibly other crops and, therefore, could be useful for global research and agricultural communities.

\section{Conclusions}

In this study, fungal metabolites of three Trichoderma spp. (i.e., T. harzianum, T. virens and T. koningii) obtained on three different growth media (STP, MOF and SuM) were tested in vitro for their anti-bacterial activity and in vivo for their anti-bacterial potential to manage bacterial wilt disease caused by R. solanacearum in tomato plants. Fungal metabolites of $T$. harzianum obtained on the STP medium were most effective in the management of $R$ solanacearum. T. harzianum metabolites caused the maximum decrease in soil bacterial populations, resulted in lowered disease severity and enhanced plant growth. The results from this study suggest that $T$. harzianum metabolites can be used as eco-friendly, cost-effective and efficient tools to manage $R$. solanacearum in tomato plants and possibly other plants.

Supplementary Materials: The following are available online at https:/ / www.mdpi.com/2071-1 050/13/3/1491/s1, Table S1: Composition of five growth media used for the production of fungal metabolites.

Author Contributions: Conceptualization, Z.Z. and R.A.A.K.; methodology, Y.Z.; formal analysis, R.A.A.K.; investigation, Y.G.; data curation, X.Y.; writing-original draft preparation, Y.G. and Z.F.; writing-review and editing, Z.Z. All authors have read and agreed to the published version of the manuscript.

Funding: This research was funded in part by the School-enterprise cooperation project of basic scientific research funds of provincial undergraduate universities in the Heilongjiang Province of China. (135409503).

Institutional Review Board Statement: Not applicable.

Informed Consent Statement: Not applicable.

Data Availability Statement: The data of this study have been presented in the manuscript.

Conflicts of Interest: The authors declare no conflict of interest. 


\section{References}

1. FAOSTAT. 2019. Available online: http://www.fao.org/faostat/en/\#home (accessed on 15 April 2019).

2. Martí, R.; Roselló, S.; Cebolla-Cornejo, J. Tomato as a source of carotenoids and polyphenols targeted to cancer prevention. Cancers (Basel) 2016, 8, E58. [CrossRef] [PubMed]

3. Krauss, S.; Schnitzler, W.H.; Grassmann, J.; Woitke, M. The influence of different electrical conductivity values in a simplified recirculating soilless system on inner and outer fruit quality characteristics of tomato. J. Agric. Food Chem. 2006, 54, 441-448. [CrossRef] [PubMed]

4. Li, Y.; Wang, H.; Zhang, Y.; Martin, C. Can the world's favorite fruit, tomato, provide an effective biosynthetic chassis for high-value metabolites? Plant Cell Rep. 2018, 37, 1443-1450. [CrossRef] [PubMed]

5. Raiola, A.; Rigano, M.M.; Calafiore, R.; Frusciante, L.; Barone, A. Enhancing the health promoting effects of tomato fruit for biofortified food. Med. Inflamm. 2014. [CrossRef]

6. Liu, Z.; Alseekh, S.; Brotman, Y.; Zheng, Y.; Fei, Z.; Tieman, D.M. Identification of a Solanum pennellii Chromosome 4 Fruit Flavor and Nutritional Quality-Associated Metabolite QTL. Front. Plant Sci. 2016, 7, 1671. [CrossRef]

7. Huo, J.Y. The current status of tomato industry in China and its safety precautions. Vegetables 2016, 6, 1-4.

8. Ma, Z.H. The change trend of tomato varieties in China based on the demand of production market. China Veg. 2017, 3, 1-5.

9. Hayward, A.C. Biology and epidemiology of bacterial wilt caused by Pseudomonas solanacearum. Annu. Rev. Phytopathol. 1991, $29,65-87$. Available online: http:/ / pascal-francis.inist.fr/vibad/index.php?action=getRecordDetail\&idt=6123393 (accessed on 5 February 1991). [CrossRef]

10. Artal, R.B.; Gopalakrishnan, C.; Thippeswamy, B. An efficient in- oculation method to screen tomato, brinjal and chilli entries for bacterial wilt resistance. Pest Manag. Hortic. Ecosyst. 2012, 18, 70-73.

11. Singh, S.; Gautam, R.K.; Singh, D.R.; Sharma, T.V.R.S.; Sakthivel, K.; Dam Roy, S. Genetic approaches for mitigating losses caused by bacterial wilt of tomato in tropical islands. Eur. J. Plant Pathol. 2015, 143, 205-222. [CrossRef]

12. Singh, S.; Singh, D.R.; Kumar, K.; Birah, A. Eco-friendly manage- ment modules for bacterial wilt (Ralstonia solanacearum) of tomato for protected cultivation in a tropical island ecosystem. Biol. Agric. Hortic. 2014, 30, 219-227. [CrossRef]

13. Jiang, G.; Wei, Z.; Xu, J.; Chen, H.; Zhang, Y.; She, X.; Macho, A.P.; Ding, W.; Liao, B. Bacterial wilt in China: History, current status, and future perspectives. Front. Plant Sci. 2017, 8, 1549. [CrossRef] [PubMed]

14. Wang, G.P.; Yuan, S.Q.; Xiong, Z.K.; Lin, M.B. The general situation of related studies on tomato bacterial spot in Guangdong Province. Guangdong Agric. Sci. 2003, 3, 32-34.

15. Wei, Z.; Yang, X.M.; Yin, S.X.; Shen, Q.R.; Ran, W.; Xu, Y.C. Efficacy of Bacillus -fortified organic fertiliser in controlling bacterial wilt of tomato in the field. Appl. Soil Ecol. 2011, 48, 152-159. [CrossRef]

16. Wei, Z.; Huang, J.F.; Hu, J.; Gu, Y.A.; Yang, C.L.; Mei, X.L.; Shen, Q.R.; Xu, Y.C.; Friman, V.P. Altering transplantation time to avoid periods of high temperature can efficiently reduce bacterial wilt disease incidence with tomato. PLoS ONE 2015, 10, e0139313. [CrossRef] [PubMed]

17. Mansfield, J.; Genin, S.; Magori, S.; Citovsky, V.; Sriariyanum, M.; Ronald, P. Top 10 plant pathogenic bacteria in molecular plant pathology. Mol. Plant Pathol. 2012, 13, 614-629. [CrossRef] [PubMed]

18. Lowe-Power, T.M.; Hendrich, C.G.; von Roepenack-Lahaye, E.; Li, B.; Wu, D.; Mitra, R. Metabolomics of tomato xylem sap during bacterial wilt reveals Ralstonia solanacearum produces abundant putrescine, a metabolite that accelerates wilt disease. Environ. Microbiol. 2018, 20, 1330-1349. [CrossRef]

19. Lowe-Power, T.M.; Khokhani, D.; Allen, C. How Ralstonia solanacearum exploits and thrives in the flowing plant xylem environment. Trends Microbiol. 2018, 26, 929-942. [CrossRef]

20. Graham, J.; Jones, D.A.; Lloyd, A.B. Survival of Pseudomonas solanacearum race-3 in plant debris and in latently infected potatotubers. Phytopathology 1979, 69, 1100-1103. [CrossRef]

21. Grey, B.E.; Steck, T.R. The viable but nonculturable state of Ralstonia solanacearum may be involved in long-term survival and plant infection. Appl. Environ. Microbiol. 2001, 67, 3866-3872. [CrossRef]

22. Hyde, K.D.; Soytong, K. The fungal endophyte dilemma. Fungal Divers. 2008, 33, e173.

23. Meyer, V. Genetic engineering of filamentous fungi-Progress, obstacles and future trends. Biotechnol. Adv. 2008, 26, 177-185. [CrossRef] [PubMed]

24. Harman, G.E.; Howell, C.R.; Viterbo, A.; Chet, I.; Lorito, M. Trichoderma species-opportunistic avirulent plant symbionts. Nat. Rev. Microbiol. 2004, 2, 43-56. [CrossRef] [PubMed]

25. Ming, Q.; Han, T.; Li, W.; Zhang, Q.; Zhang, H.; Zheng, C. Tanshinone II A and tanshinone I production by Trichoderma atroviride D16, an endophytic fungus in Salvia miltiorrhiza. Phytomedicine 2012, 19, 330-333. [CrossRef] [PubMed]

26. Monte, E. Understanding Trichoderma: Between agricultural biotechnology and microbial ecology. Int. Microbiol. 2001, 4, 1-4. [PubMed]

27. Vizcaino, J.A.; Sanz, L.; Cardoza, R.E.; Monte, E.; Gutierrez, S. Detection of putative peptide synthetase genes in Trichoderma species. Application of this method to the cloning of a gene from T. harzianum CECT 2413. FEMS Microbiol. Let. 2005, 244, 139-148. [CrossRef] [PubMed]

28. Vinale, F.; Sivasithamparam, K.; Ghisalberti, E.L.; Woo, S.L.; Nigro, M.; Marra, R. Trichoderma secondary metabolites active on plants and fungal pathogens. Open Mycol. J. 2008, 8, 127-139. [CrossRef] 
29. Sivasithamparam, K.; Ghisalberti, E.L. Secondary metabolism in Trichoderma and Gliocladium. In Trichoderma and Gliocladium. Basic Biology, Taxonomy and Genetics; Kubicek, C.P., Harman, G.E., Eds.; Taylor \& Francis: London, UK, 1998; Volume 1, pp. 139-191.

30. Luckner, M. Secondary Metabolism in Microorganisms, Plants and Animals, 3rd ed.; Springer: Berlin, Germany, 1990.

31. Mohamed, B.F.F.; Sallam, N.M.A.; Alamri, S.A.M. Approving the biocontrol method of potato wilt caused by Ralstonia solanacearum (Smith) using Enterobacter cloacae PS14 and Trichoderma asperellum T34. Egypt J. Biol. Pest Control 2020, $30,61$. [CrossRef]

32. Kariuki, C.K.; Mutitu, E.W.; Muiru, W.M. Effect of Bacillus and Trichoderma species in the management of the bacterial wilt of tomato (Lycopersicum esculentum) in the field. Egypt. J. Biol. Pest Control 2020, 30, 109. [CrossRef]

33. Khan, R.A.A.; Najeeb, S.; Mao, Z.; Ling, J.; Yang, Y.; Li, Y.; Xie, B. Bioactive Secondary Metabolites from Trichoderma spp. against Phytopathogenic Bacteria and Root-Knot Nematode. Microorganisms 2020, 8, 401. [CrossRef]

34. Tong, X.; Shen, X.Y.; Hou, C.L. Antimicrobial activity of fungal endophytes from Vaccinium dunalianum var. urophyllum. Sains. Malaysiana 2018, 47, 1685-1692. [CrossRef]

35. Kamonwannasit, S.; Nantapong, N.; Kumkrai, P.; Luecha, P.; Kupittayanant, S.; Chudapongse, N. Antibacterial activity of Aqularia crassna leaf extract against Staphylococcus epidermis by disruption of cell wall. Ann. Clin. Microbiol. Antimicrob. 2013, 12, 20. [CrossRef] [PubMed]

36. Najeeb, S.; Ahmad, M.; Khan, R.A.A.; Naz, I.; Ali, A.; Alam, S.S. Management of bacterial wilt in tomato using dried powder of Withania coagulan (L) Dunal. Austral. Plant Pathol. 2019, 48, 183-192. [CrossRef]

37. Gruter, D.; Schmid, B.; Brandl, H. Influence of plant diversity and elevated atmospheric carbon dioxide levels on below ground bacterial diversity. BMC Microbiol. 2006, 6, 68. [CrossRef] [PubMed]

38. Goszczynska, T.; Serfontein, J.J.; Serfontein, S. Media and Diagnostic Tests, Introduction to Practical Phytobacteriology, Bacterial Diseases Unit; ARC-Plant Protection Research Institute: Pretoria, South Africa, 2000; pp. 60-73.

39. Abdel-Monaaim, M.F.; Abo-Elyousr, K.M.; Morsy, K.M. Effectiveness of plant extracts on suppression of damping-off and wilt diseases of lupine (Lupinustermis forsik). Crop Prot. 2011, 30, 185-191. [CrossRef]

40. Madden, L.V.; Hughes, G.; Van den, B. The Study of Plant Disease Epidemics; APS Press: Minnesota, MN, USA, 2007; Available online: https:/ / apsjournals.apsnet.org/doi/pdf/10.1094/9780890545058.fm (accessed on 7 May 2007).

41. Gomez, K.A.; Gomez, A.A. Statistical Procedures for Agricultural Research; John Wiley and Sons: New York, NY, USA, 1984.

42. Xiao-yan, S.; Qing-tao, S.; Shu-tao, X.; Xiu-lan, C.; Cai-yan, S.; Yu-zhong, Z. Broad-spectrum antimicrobial activity and high stability of Trichokonins from Trichoderma koningii SMF2 against plant pathogens. FEMS Microbiol. Lett. 2006, 260, 119-125. [CrossRef]

43. Utkhede, R.; Koch, C. Biological treatments to control bacterial canker of greenhouse tomatoes. Biocontrology 2004, 49, 305-313. [CrossRef]

44. El-Hasan, A.; Walker, F.; Schöne, J.; Buchenauer, H. Detection of viridiofungin A and another antifungal metabolites excreted by Trichoderma harzianum active against different plant pathogens. Eur. J. Plant Pathol. 2009, 124, 457-470. [CrossRef]

45. Tanaka, J.C.A.; da Silva, C.C.; de Oliveira, A.J.B.; Nakamura, C.V.; Dias, B.P. Antibacterial activity of indole alkaloids from Aspidosperma ramiflorum. Braz. J. Med. Biol. Res. 2006, 39, 387-391. [CrossRef]

46. Tsuchiya, H. Memberane interactions of phytochemicals as their molecular mechanism applicable to the discovery of drug leads from plants. Molecules 2015, 20, 18923-18966. [CrossRef]

47. Plaper, A.; Golob, M.; Hafner, I.; Oblak, M.; Solmajer, T.; Jerala, R. Characterization of quercetin binding site on DNA gyrase. Biochem. Biophy. Res. Commu. 2003, 306, 530-536. [CrossRef]

48. Zhang, L.; Kong, Y.; Wu, D.; Zhang, H.; Wu, J.; Chen, J.; Ding, J.; Hu, L.; Jiang, H.; Shen, X. Three flavonoids targeting the beta-hydroxyacyl-acyl carrier protein dehydratase from Helicobacter pylori: Crystal structure characterization with enzymatic inhibition assay. Protein Sci. 2008, 17, 1971-1978. [CrossRef] [PubMed]

49. Saito, H.; Sakakibara, Y.; Sakata, A.; Kurashige, R.; Murakami, D.; Kageshima, H.; Saito, A.; Miyazaki, Y. Antibacterial activity of lysozyme-chitosan oligosaccharide conjugates (LYZOX) against Pseudomonas aeruginosa, Acinetobacter baumannii and Methicillinresistant Staphylococcus aureus. PLoS ONE 2019, 14, e0217504. [CrossRef] [PubMed]

50. Benitez, T.; Rincón, A.M.; Limón, M.C.; Codón, A.C. Biocontrol mechanisms of Trichoderma strains. Int. Microbiol. 2004, 7, 249-260.

51. Contreras-Cornejo, H.A.; Macìas-Rodrìguez, L.; Cortés-Penagos, C.; López-Bucio, J. Trichoderma virens, a plant beneficial fungus, enhances biomass production and promotes lateral root growth through an auxin-dependent mechanism in Arabidopsis. $\mathrm{Pl}$. Physiol. 2009, 149, 1579-1592. [CrossRef]

52. Hoyos-Carvajal, L.; Orduz, S.; Bissett, J. Growth stimulation in bean (Phaseolus vulgaris L.) by Trichoderma. Biol. Cont. 2009, 51, 409-416. [CrossRef]

53. Cutler, H.G.; Cox, R.H.; Crumley, F.G.; Cole, P.D. 6-Pentyl- $\alpha$-pyrone from Trichoderma harzianum: Its plant growth inhibitory and antimicrobial properties. Agric. Biol. Chem. 1986, 50, 2943-2945. [CrossRef]

54. Cutler, H.G.; Himmetsbach, D.S.; Arrendale, R.F.; Cole, P.D.; Cox, R.H. Koninginin A: A novel plant regulator from Trichoderma koningii. Agri. Biol. Chem. 1989, 53, 2605-2611. [CrossRef]

55. Parker, S.R.; Cutler, H.G.; Jacyno, J.M.; Hill, R.A. Biological activity of 6-pentyl-2H-pyran-2-one and its analogs. J. Agri. Food Chem. 1997, 45, 2774-2776. [CrossRef] 
56. Parker, S.R.; Cutler, H.G.; Schreiner, P.R. Koninginin E: Isolation of a biologically active natural product from Trichoderma koningii. Biosc. Biotechnol. Biochem. 1995, 59, 1747-1749. [CrossRef]

57. Macias, F.A.; Varela, R.M.; Simonet, A.M.; Cutler, H.G.; Cutler, S.J.; Eden, M.A.; Hill, R.A. Bioactive carotanes from Trichoderma virens. J. Nat. Prod. 2000, 63, 1197-1200. [CrossRef] [PubMed]

58. Cutler, H.G.; Jacyno, J.M.; Phillips, R.S.; von Tersch, R.L.; Cole, P.D.; Montemurro, N. Cyclonerodiol from a novel source, Trichoderma koningii: Plant growth regulatory activity. Agric. Biol. Chem. 1991, 55, 243-244. [CrossRef]

59. Ghisalberti, E.L.; Rowland, C.Y. Antifungal metabolites from Trichoderma harzianum. J. Nat. Prod. 1993, 56, 1799-1804. [CrossRef] [PubMed]

60. Khan, R.A.A.; Bilal, A.; Musharaf, A.; Asad, A.; Ishrat, N.; Muhammad, F. Management of Ralstonia solanacearum (Smith) Yabuuchi wilt in tomato (Solanum lycopersicum L.) with dried powder of the medicinal plant Withania somnifera (L.) Dunal. Pak. J. Bot. 2019, 51, 297-306. [CrossRef] 